\title{
UTJECAJ RASPOREDA LEŽAJEVA NA NAPREZANJA RASPONSKOGA SKLOPA PLOČASTOG MOSTA
}

\author{
Tea Juzbašić \\ Sveučilište J. J. Strossmayera u Osijeku, Građevinski Fakultet Osijek, student \\ Juraj Popović \\ Sveučilište J. J. Strossmayera u Osijeku, Građevinski Fakultet Osijek, student \\ Hrvoje Draganić \\ Sveučilište J. J. Strossmayera u Osijeku, Građevinski Fakultet Osijek, dipl.ing.građ.
}

Sažetak: Ležajevi su elementi kojima se prenose različita djelovanja s rasponskoga sklopa na potpore. Oni su veza gornjeg i donjeg ustroja mosta. Predviđeno funkcioniranje ležajeva treba biti ispunjeno kroz cio vijek trajanja mosta, a ako neke konstrukcije ne udovoljavaju zadanim uvjetima okoliša, potrebno je predvidjeti mogućnost njihove zamjene. Slika unutarnjih sila u elementima donjeg i gornjeg ustroja mosta je bitno određena rasporedom njegovih ležajeva. Stoga je potrebno dobro razmotriti njihov raspored. $U$ radu će se dati pregled nekoliko rasporeda ležajeva i njihov utjecaj na naprezanja u pločastom rasponskom sklopu te raspodjelu momenata savijanja u naglavnim gredama.

Ključne riječi: ležajevi, raspored ležajeva, pločasti rasponski sklop, naglavne grede, naprezanje rasponskoga sklopa

\section{INFLUENCE OF THE BEARING DISPOSITION ON STRESSES IN THE SLAB BRIDGE SUPERSTRUCTURE}

\begin{abstract}
Bearings are elements that transfer loads from the bridge superstructure to the foundation. Bearings are conections between the bridge superstructure and substructure (fundations). Anticipated functioning of the bearins should be provided during the entire life span of the bridge. If a structure does not meet the specified environmental conditions it is necessary to provide replacement of the bearings. Layout of internal forces in elements of the substructure and the superstructure of the bridge is essentially determined by the layout of its bearings. It is therefore necessary to consider their disposition. The paper reviews several layouts of bearings and their influence on the stresses in a slab bridge superstructure and distribution of bending moments in head beams.
\end{abstract}

Key words: bearings, layout of bearings, slab superstructure, head beam, stresses in a superstructure 


\section{Uvod}

Mostovi su podložni pomacima pod djelovanjem temperature, elastičnih naprezanja uzrokovanih različitim djelovanjima, posebice prometnim opterećenjem. Ležajevi su elementi kojima se sile nastale ovim djelovanjima prenose na potpore. Prilikom projektiranja mosta ležajeve treba razmatrati kao vezne elemente između cjelovitog rasponskog sklopa i donjeg ustroja. Sile na ležajeve uobičajeno se rastavljaju na horizontalnu i vertikalnu komponentu. Ležajevi koji preuzimaju vertikalne sile obično omogućuju zakretanje u jednom smjeru, dok neki i u svim smjerovima. Prijenos vertikalnih sila se najčešće kombinira s prijenosom horizontalnih sila.

Prvi ležajevi bili su jednostavni kontaktni, načinjeni od čelika. U novije vrijeme razvijeni su ležajevi koji prenose opterećenje preko veće površine, nasuprot čeličnima koji opterećenje prenose točkasto ili linijski. Za nove tipove ležajeva riješen je problem prijenosa opterećenja i omogućavanja pomaka u svim smjerovima (elastomerni ležajevi), ali je njihova trajnost još upitna.

Projektom predviđeno funkcioniranje ležajeva treba biti ispunjeno kroz cio vijek trajanja mosta u zadanim uvjetima okoliša. Budući da neke konstrukcije ne udovoljavaju tim uvjetima, već u samom projektu treba biti predviđena mogućnost njihove zamjene [2].

\section{Ležajevi}

Ležajevi su konstrukcijski elementi koji služe za prijenos opterećenja s rasponskog sklopa na potpore (stupove i upornjake). Zadaća je ležajeva prihvatiti reakcije rasponske konstrukcije i usmjeriti ih tako da smjerovi njihova djelovanja budu određeni. Omogućuju horizontalne i vertikalne pomake, te prenose momente savijanja i torzije. Omogućuju ili sprječavaju pomake i zaokretanje rasponskoga sklopa. Prema funkcionalnosti, ležajeve možemo podijeliti na:

- upete

- nepomične

- pomične

- elastične.

Upeti ležajevi

- homogeno spojeni s upornjacima ili sa stupovima, ili s temeljima kod svođenih mostova

- preuzimaju sve unutarnje sile i ne dopuštaju niti jedan pomak.

Nepomični (nepokretni) ležajevi

- omogućuju zaokretanje rasponskoga sklopa

- prenose horizontalne i vertikalne sile

- $\quad$ točkasti se mogu zaokretati u svim smjerovima (ne prenose niti jedan moment savijanja)

- linijski se zaokreću samo u jednoj ravnini (ne prenose moment savijanja u toj ravnini).

Pomični (pokretni) ležajevi

- mogu se pomicati u smjeru uzduž mosta, okomito na os mosta ili u oba smjera

- ne mogu prihvatiti silu u smjeru u kojemu je omogućen translacijski pomak

- ne mogu prihvatiti moment savijanja u smjeru omogućenog rotacijskog pomaka

- točkasti i linijski

- teoretski omogućuju ostvarivanje pomaka bez otpora

- u praksi, u njima nastaju određene unutarnje sile zbog:

○ trenja kotrljanja

- trenja klizanja

o deformacijskog otpora u elastomeru.

Elastični ležajevi

- pomaci su ograničeni djelovanjem "elastične opruge"

- ima mnogo zaštićenih (patentiranih) sustava

- neke vrste prikladne su za preuzimanje sila potresa na upornjacima mosta. 


\section{Raspored ležajeva}

Mostovi su izloženi različitim utjecajima koji uzrokuju pomake kolničke ploče i njegovih oslonaca. Uzroci ovih pomaka mogu biti sljedeći [3]:

- temperaturne promjene (jednolike i nejednolike)

- skupljanje i puzanje betona

- stalno djelovanje (progib - zaokret)

- prometno djelovanje (progib - zaokret)

- progib i zaokret zbog horizontalnog djelovanja

- slijeganje ležajeva

- potisak tla na upornjake

- progib vitkih stupova

- udarac vozila

- učinak seizmičkoga djelovanja.

Osnovni principi za izbor tipa ležajeva i njihov razmještaj jesu:

- minimiziranje broja ležajeva i prijelaznih naprava kod kontinuiranih sustava;

- omjer raspona i izvedba detalja gornjeg ustroja tako da se osigura da ne dođe do odizanja ležajeva za bilo koju kombinaciju djelovanja;

- samo na jednoj potpori predvidjeti nepomičnost u uzdužnom smjeru;

- na svakoj potpori predvidjeti samo jedno bočno pridržanje;

- za vrijeme ugradbe predvidjeti potrebu za privremenim bočnim pridržanjem nosača (odabrati mjesta trajnih pridržanja da istovremeno služe kao privremena);

- razmatranje problema na kojemu će kraju most imati nepokretan ležaj;

- birati pokretne i nepokretne ležajeve s minimalnim vertikalnim opterećenjem uz maksimalno horizontalno opterećenje;

- na čeličnim mostovima izbjegavati zatvorene pomične prijelazne naprave, osim ako su rasponi mosta vrlo mali ili je most izveden kao integralni.

Suvremena iskustva građenja i uzdržavanja velikih masivnih mostova dovela su do zaključka da bi trebalo konstrukciju i stupove povezati kruto gdje god stupovi mogu slijediti i bez oštećenja podnijeti pomake rasponske konstrukcije. Ako je potrebno izvesti zglobnu vezu između stupova i konstrukcije i/ili između stupova i temelja, to valja nastojati ostvariti betonskim zglobovima. Tek kada je ovo neostvarivo, ugrađuju se pokretni i nepokretni ležajevi.

Slika unutarnjih sila u elementima donjeg i gornjeg ustroja mosta bitno je određena rasporedom njegovih ležajeva. Rasponski sklop i stupovi mogu biti kruto povezani dokle god mogu slijediti pomake rasponske konstrukcije elastičnim deformacijama. Ponekad je povoljnije umjesto krute ostvariti zglobnu vezu, konstrukcija pri tome ostaje monolitna, a trajnost samog mjesta oslanjanja odgovara trajnosti rasponskoga sklopa. 
a)

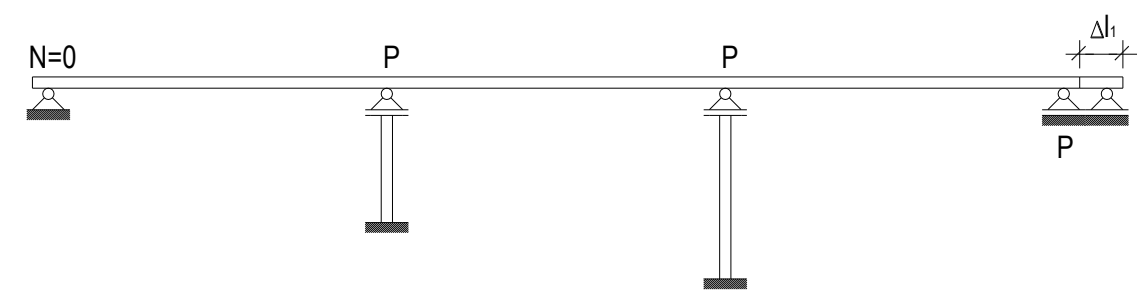

b)

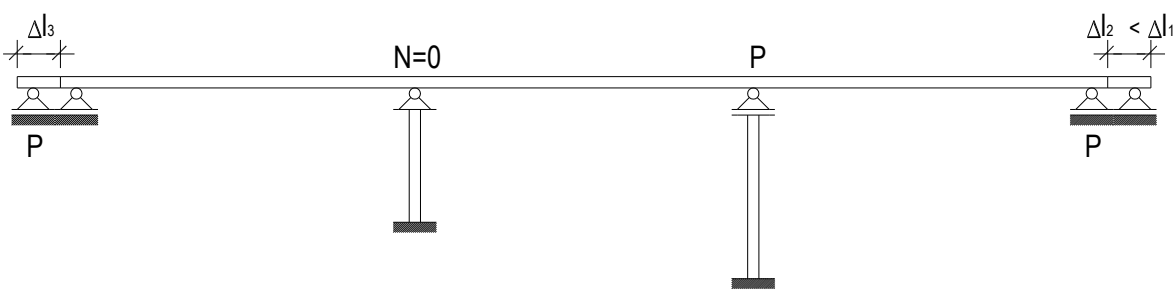

c)

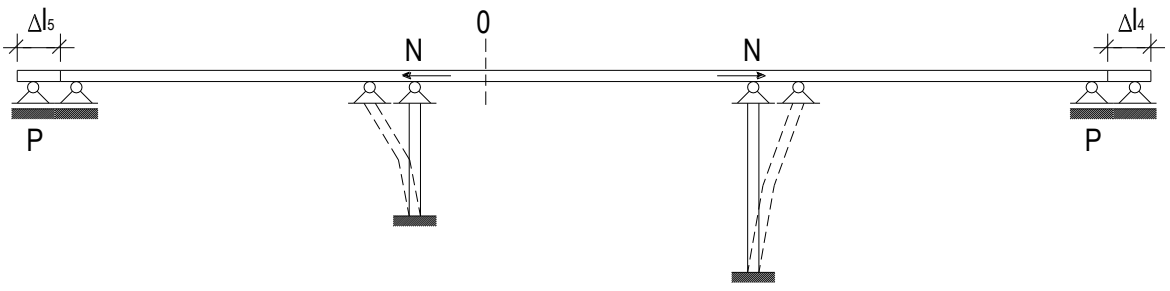

d)

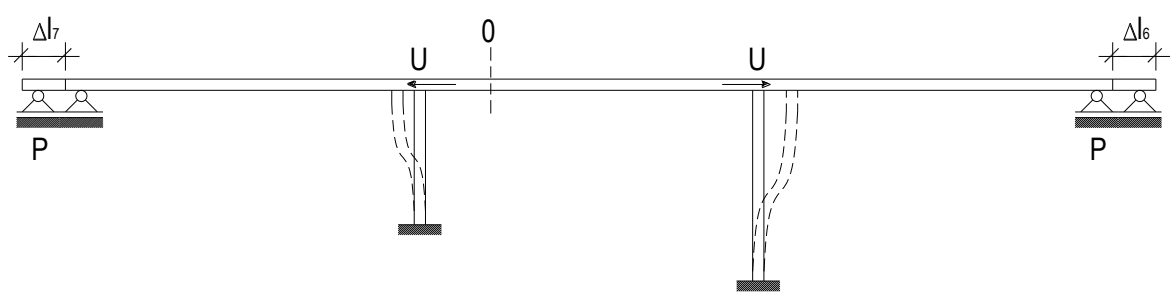

e)

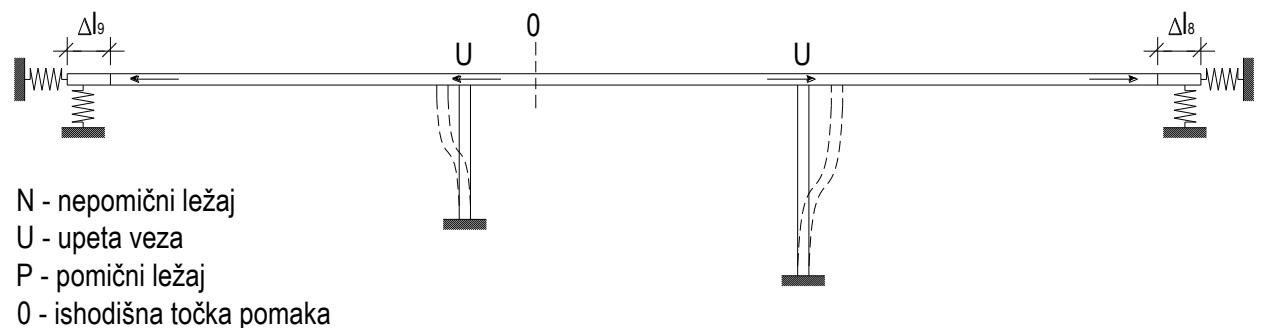

Slika 1 - Različiti rasporedi ležajeva mosta

Uvriježeni raspored u kojem se nepomični ležaj nalazi na upornjaku na kojemu je najlakše prenijeti horizontalne sile, izaziva najveće pomake na suprotnom upornjaku (slika 1 a) ). Jedan od stupova preuzima horizontalne sile, pri čemu su pomaci na krajevima koje je potrebno premostiti prijelaznim napravama manji (slika 1 b) ). Kod vitkih stupova, na više njih možemo postaviti nepomične ležajeve te time raspoređujemo horizontalnu silu uzduž mosta (slika $1 \mathrm{c}$ ) ). Stupovi su upeti u rasponski sklop, što daje okvirnu konstrukciju koja ima svojih prednosti (slika 1 d) ). Integralni most, bez ležajeva i prijelaznih naprava (slika 1 e) ). Kod mostova malih i srednjih raspona, ekonomičnijim se pokazalo preuzimanje sile od ograničenih pomaka nego ugrađivanje i uzdržavanje ležajeva. Pri rasporedima a) i b), ishodište pomaka nastalih zbog skupljanja, puzanja i temperature određeno je položajem nepomičnog ležaja, te se u konstrukciji ne javljaju dodatne sile od spriječenih pomaka. Kod ostalih rasporeda ta nepomična točka traži se računski iz omjera krutosti elemenata potpora, te se pojavljuju dodatne sile od spriječenih pomaka i s njima valja računati. 


\section{Tablica 1 - Pregled simbola ležajeva}

\begin{tabular}{|c|c|c|}
\hline simbol & funkcija & konstrukcija \\
\hline & $\begin{array}{ll}\text { - } & \text { svi translatorni pomaci spriječeni } \\
\text { - } & \text { zaokretanje omogućeno u svim } \\
& \text { smjerovima }\end{array}$ & $\begin{array}{ll}- & \text { točkasti zaokretni ležaj } \\
- & \text { točkasti nepomični ležaj } \\
- & \text { elastomerni ležaj s uređajem za } \\
& \text { sprječavanje pomaka } \\
- & \text { sferni ležaj }\end{array}$ \\
\hline & $\begin{array}{ll}- & \text { horizontalni pomak u jednom smjeru } \\
- & \text { zaokretanje omogućeno u svim } \\
\text { smjerovima }\end{array}$ & $\begin{array}{ll}- & \text { točkasti zaokretni ležaj s kliznom } \\
& \text { pločom i vodilicom } \\
- & \text { lončasti, jednosmjerno pomični ležaj } \\
- & \text { jednosmjerno pomični sferni ležaj } \\
\end{array}$ \\
\hline 4 & $\begin{array}{ll} & \text { horizontalni pomak u svim smjerovima } \\
- & \text { zaokretanje omogućeno u svim } \\
& \text { smjerovima }\end{array}$ & $\begin{array}{ll}- & \text { točkasti zaokretni ležaj s omogućenim } \\
& \text { pomacima u svim smjerovima (s } \\
& \text { kliznom pločom) } \\
- & \text { lončasti pomični ležaj (klizni) } \\
- & \text { sferni ležaj s kliznom pločom }\end{array}$ \\
\hline & $\begin{array}{ll} & \text { svi translatorni pomaci spriječeni } \\
- & \text { zaokretanje omogućeno oko jedne osi }\end{array}$ & - linijski zaokretni ležaj \\
\hline & $\begin{array}{ll}- & \text { horizontalni pomak u jednom smjeru } \\
- & \text { zaokretanje omogućeno oko jedne osi }\end{array}$ & $\begin{array}{ll}- & \text { kotrljajući ležaj } \\
- & \text { ležaj-njihalo (,pendl“) }\end{array}$ \\
\hline & $\begin{array}{ll}- & \text { svi translatorni pomaci spriječeni } \\
- & \text { zaokretanje omogućeno u svim } \\
& \text { smjerovima }\end{array}$ & $\begin{array}{l}\text { - ležaj za prijenos horizontalne sile (ne } \\
\text { preuzima vertikalnu reakciju) }\end{array}$ \\
\hline & $\begin{array}{ll}- & \text { horizontalni pomak u jednom smjeru } \\
- & \text { zaokretanje omogućeno u svim } \\
& \text { smjerovima } \\
\end{array}$ & $\begin{array}{l}\text { - } \quad \text { ležaj za prijenos horizontalne sile (ne } \\
\text { preuzima vertikalnu reakciju) }\end{array}$ \\
\hline & $\begin{array}{ll}- & \text { svi translatorni pomaci i zaokretanja } \\
& \text { omogućeni deformacijom }\end{array}$ & - deformabilni ležaj \\
\hline & $\begin{array}{ll}- & \text { horizontalni pomak deformacijom u } \\
& \text { jednom smjeru } \\
-\quad & \text { zaokretanje omogućeno u svim } \\
& \text { smjerovima }\end{array}$ & $\begin{array}{ll}\text { - } & \text { deformabilni ležaj s uređajem za } \\
\text { sprječavanje pomaka u jednome smjeru }\end{array}$ \\
\hline & $\begin{array}{ll}- & \text { horizontalni pomak onemogućen } \\
- & \text { zaokretanje omogućeno u svim } \\
& \text { smjerovima }\end{array}$ & $\begin{array}{l}\text { - } \quad \text { deformabilni ležaj s uređajem za } \\
\text { sprječavanje pomaka }\end{array}$ \\
\hline & $\begin{array}{ll}- & \text { horizontalni pomak u jednome smjeru } \\
- & \text { zaokretanje omogućeno u svim } \\
& \text { smjerovima }\end{array}$ & $\begin{array}{l}\text { - } \quad \text { deformabilno klizni ležaj s uređajem za } \\
\text { sprječavanje pomaka u jednom smjeru }\end{array}$ \\
\hline$\varangle$ & $\begin{array}{ll}\text { - } & \text { horizontalni pomak u svim smjerovima } \\
\text { - } & \text { zaokretanje omogućeno u svim } \\
& \text { smjerovima }\end{array}$ & - deformabilni, svestrano klizni ležaj \\
\hline & $\begin{array}{ll}- & \text { horizontalni pomak u jednome smjeru } \\
\text { klizanjem, u jednome smjeru } \\
\text { deformacijom } \\
-\quad \begin{array}{l}\text { zaokretanje omogućeno u svim } \\
\text { smjerovima }\end{array} \\
\end{array}$ & - deformabilni, jednosmjerno klizni ležaj \\
\hline
\end{tabular}

Kod tlocrtnog rasporeda ležaja jednorasponskih mostova, na svakome upornjaku treba postaviti jedan nepomičan i jedan pomičan ležaj, pri čemu su ostali ležajevi samo vertikalne potpore, pomične u bilo kojem horizontalnom smjeru. Uvriježeni raspored ležajeva na mostu $s$ dvama glavnim nosačima i jednim rasponom prikazan je na slici 2. Raspored prikazan na slici 2 a) omogućava jednoliku razdiobu uzdužnih horizontalnih sila 
na potpore, ali poprečne horizontalne sile uzrokuju dodatne sile na donji ustroj zbog spriječenih pomaka. Rasporedi pod b) i c) sprječavaju pojavu gore navedenih parazitnih djelovanja.

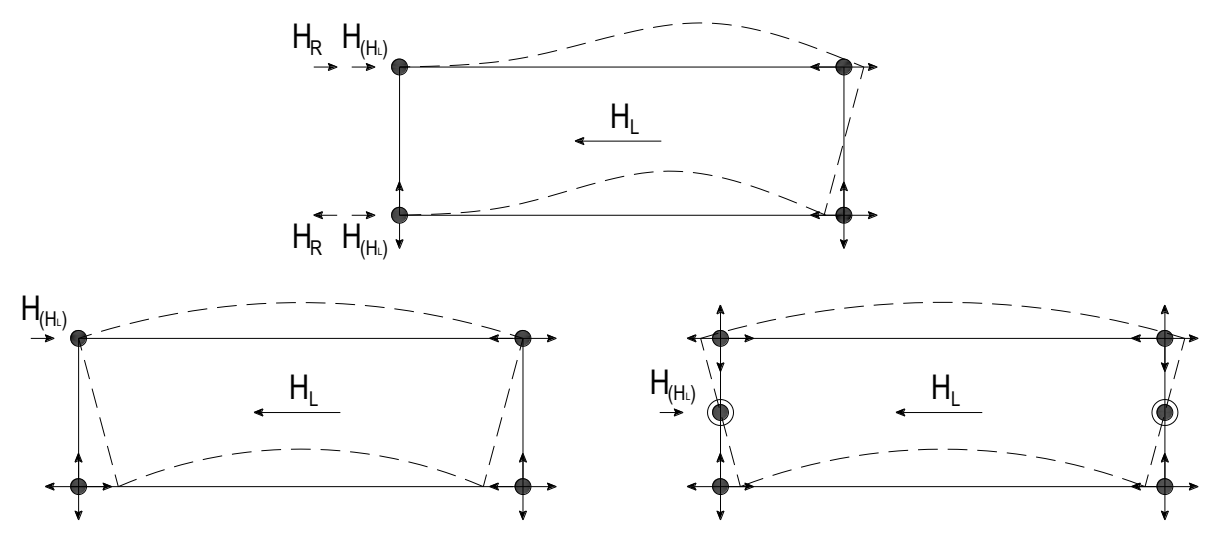

Slika 2 - Varijante tlocrtnog rasporeda ležajeva jednorasponskog mosta s dvama glavnim nosačima

Kod kontinuiranih glavnih nosača u pravilu se na stupove postavljaju ležajevi sa spriječenim poprečnim pomacima (slike 3 a) i b) ). Jedino odstupanje od ovoga pravila moguće je kod horizontalno veoma krutih konstrukcija, kod kojih se sve vodoravne sile predaju na upornjake.

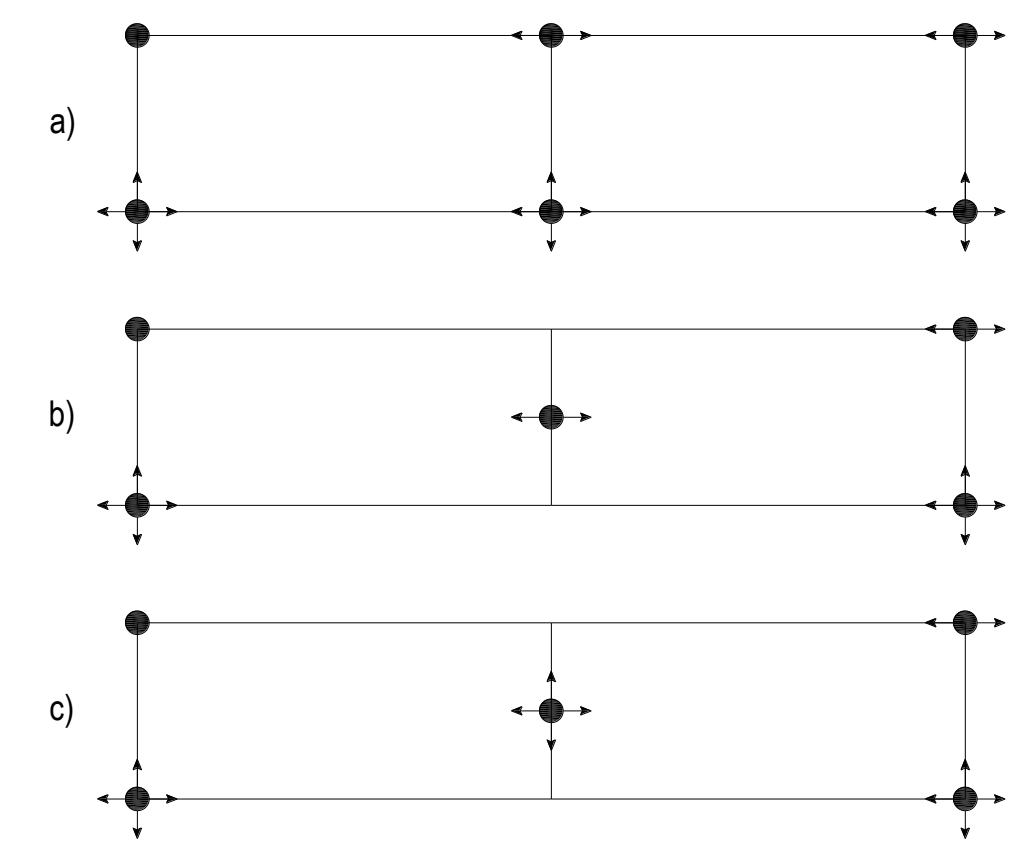

\section{Slika 3 - Varijante tlocrtnog rasporeda ležajeva kontinuiranih mostova s dvama glavnim nosačima}

Kako bi se preuzele torzijske deformacije na upornjacima i razdjelnim stupovima, koriste se najmanje dva vertikalna ležaja, dok su na srednjim stupovima moguća i rješenja s jednim vertikalnim ležajem.

$\mathrm{U}$ dosadašnjim prikazima rasporeda ležaja korištene su oznake koje prikazuju ranije konstrukcije ležaja (pri čemu su pomaci u nekom smjeru ili omogućeni ili spriječeni, tablica 1). Nasuprot ovakvim konstrukcijama deformabilni ležajevi osim vertikalnih preuzimaju i horizontalne sile, istodobno se deformirajući i time omogućavaju pomake konstrukcije (slika 4). Prednosti elastomernih ležajeva su mogućnost finog prilagođavanja veličine sile koja se prenosi na neku potporu regulacijom krutosti ležaja i smanjenjem dinamičkoga djelovanja na donji ustroj [1]. 
a) Uvriježeni raspored

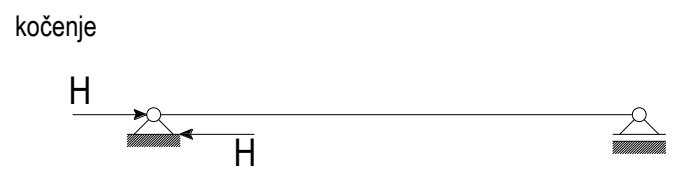

jednolika temperatura

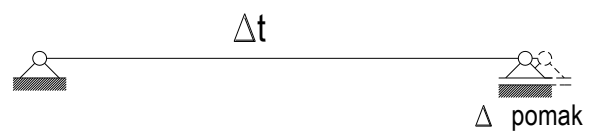

Pomak se ostvaruje s jedne, a sila prenosi s druge strane mosta. b) Elastomerni ležaj

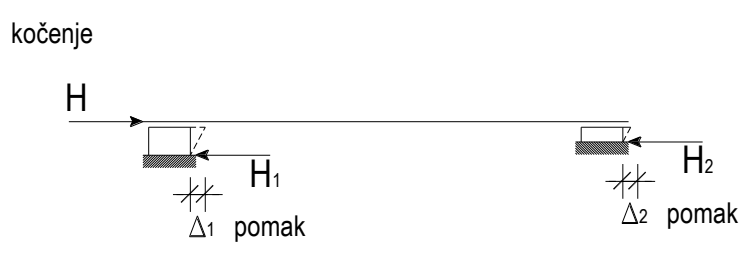

jednolika temperatura

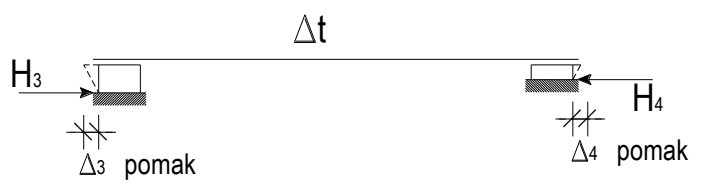

Na oba ležaja ostvaruje se pomak i prijenos sile.

\section{Slika 4 - Prijenos sila i pomaka}

Kod kosih mostova ili mostova u zavoju, osnovni princip je omogućavanje jednolikih deformacija zbog temperaturnog djelovanja ili skupljanja bez ograničenja. Postavljanje uzdužnog rasporeda je kudikamo složenije pa se koriste samo točkasti (svestrano zaokretljivi) ležajevi. Također je nužno odrediti hoće li se horizontalna sila kombinirati s manjom ili većom vertikalnom reakcijom (načelno je bolje to činiti s većom vertikalnom reakcijom, što navodi na rješenje s nepomičnim ležajem u tupom kutu mosta, slika 5).

a)

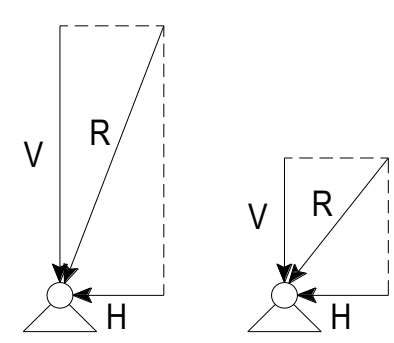

b)

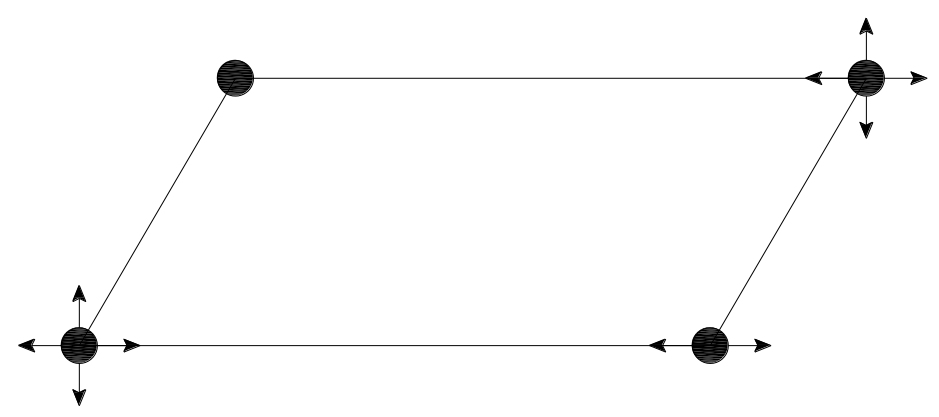

Slika 5 - Nagib rezultantne sile i raspored ležajeva kosog mosta

Glavni pomaci na mjestu prijelazne naprave trebali bi se događati u smjeru osi prometnice (najčešće se taj smjer ne poklapa sa smjerom polarne linije od nepomičnog prema pomičnom ležaju, slika 6).

Najčešći rasporedi potpora kontinuiranih mostova u krivini su tangencijalni i polarni (slika 7). Polarni raspored povoljniji je kada imamo pomake nastale djelovanjem jednolične temperature (prednost kod čeličnih mostova). Tangencijalni raspored je povoljniji za utjecaje prednapinjanja i puzanja, nejednolike temperature i pomaka uzrokovanih kočenjem. Alternativni raspored je načinjen tako da su ležajevi raspoređeni na način da imaju isti kut prema svojim polarnim osima kao i ležaj na upornjaku. 


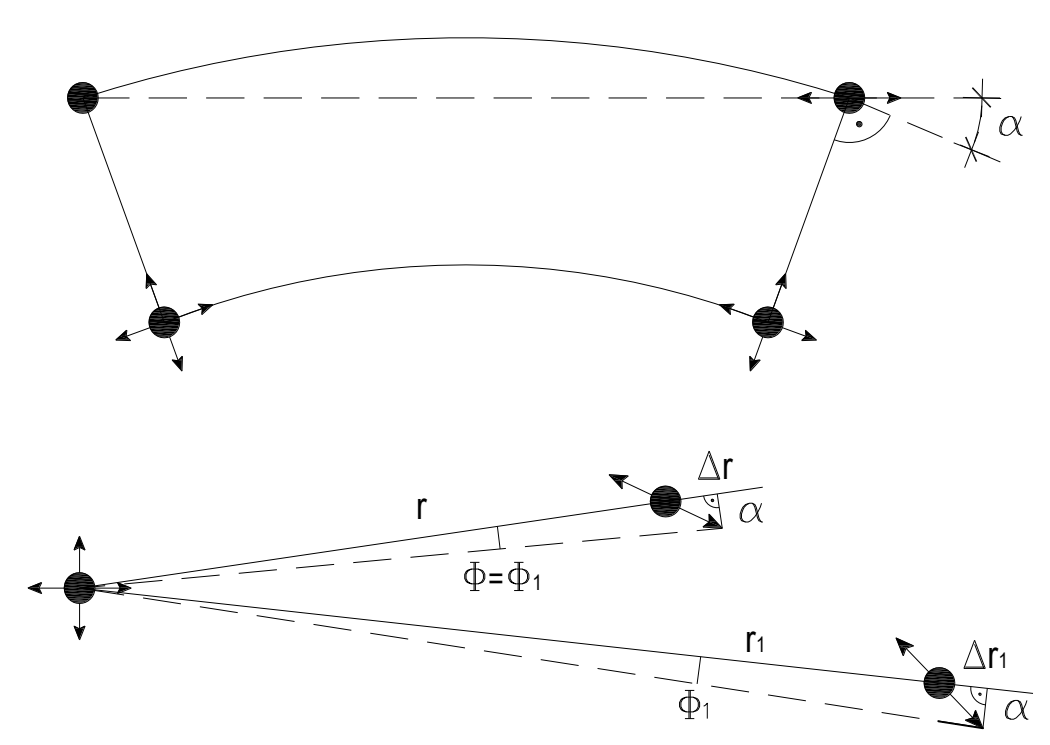

Slika 6 - Tangencijalni raspored ležajeva mosta u krivini i pripadni geometrijski odnosi

a)

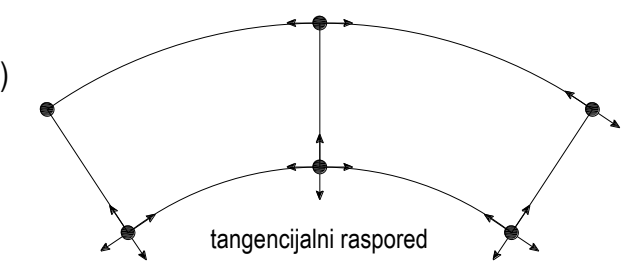

b)

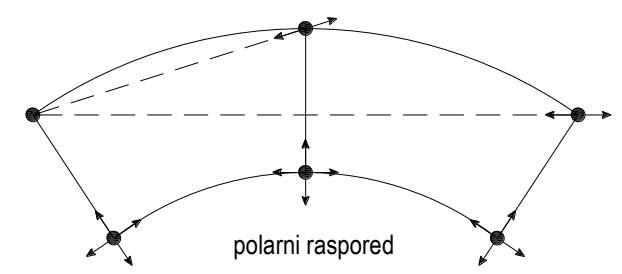

c)

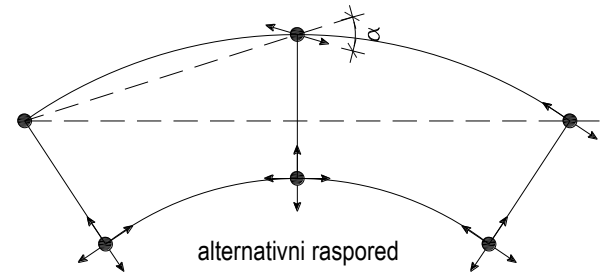

Slika 7 - Raspored ležajeva zakrivljenog mosta

\section{Naprezanja u rasponskom sklopu i ležajnoj gredi}

\subsection{Model mosta}

Kako bi se prikazale razlike u naprezanjima ovisno o različitim rasporedima ležajeva, modeliran je pločasti most u programskom paketu Robot Millennium kao prostorni model. Most je modeliran kao kombinacija ljuščanih (shell) i grednih (beam) elemenata. Ljuščanim elementima je modelirana ploča mosta, dok su ležajne grede i piloti modelirani kao gredni elementi. Krutost tla je modelirana oprugama kojima su prihvaćeni piloti. Krutost tla se mijenja s povećanjem dubine pa je sukladno tome krutost opruga varirana po visini pilota. Radi jednostavnosti, piloti su podijeljeni na tri dijela te je svakom dijelu pridružena odgovarajuća srednja krutost tla. Niže je dana geometrija mosta (slike 8a do 10). 


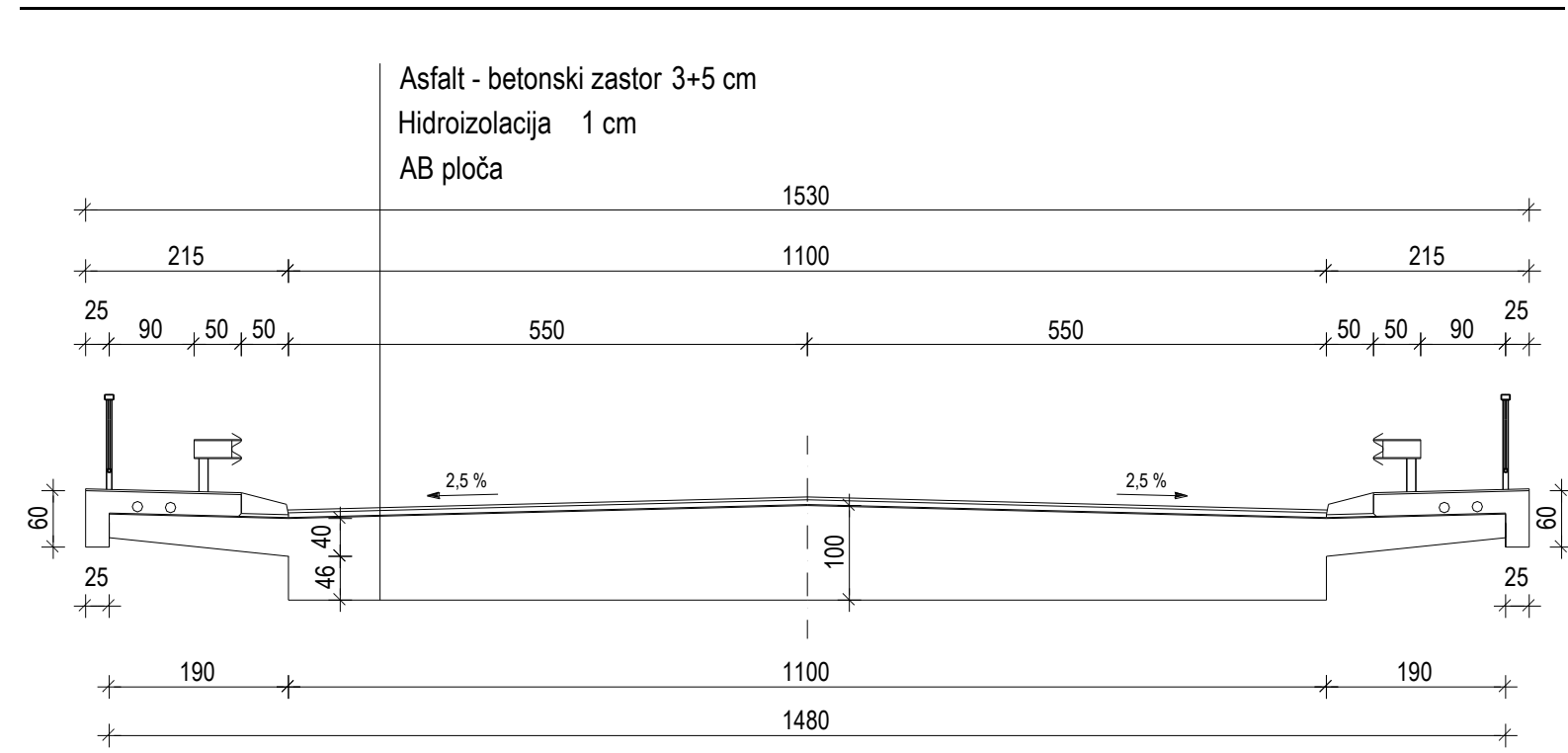

Slika 8a - Poprečni presjek pločastog mosta u polju
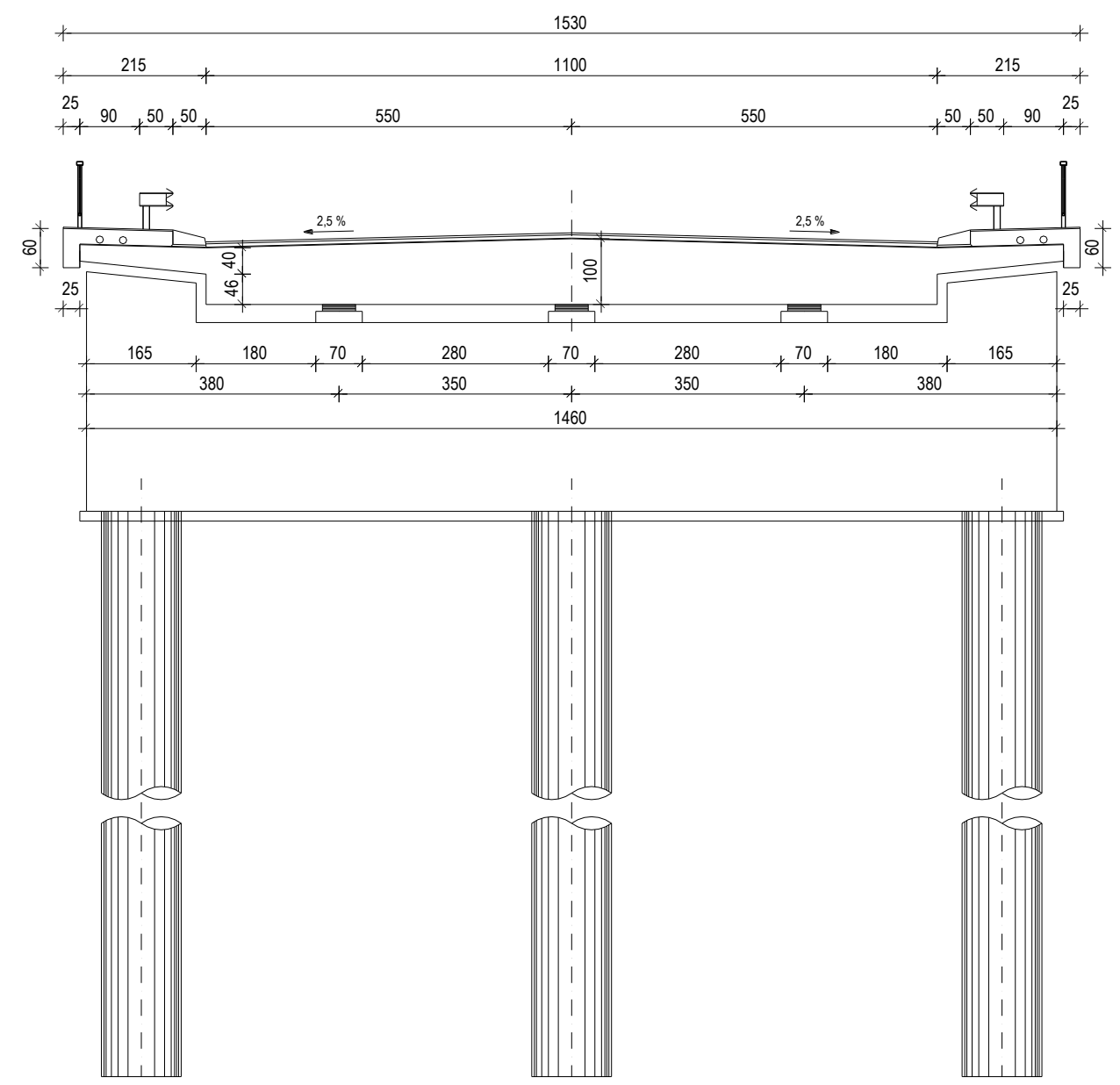

Slika 8b - Poprečni presjek pločastog mosta pri upornjaku 


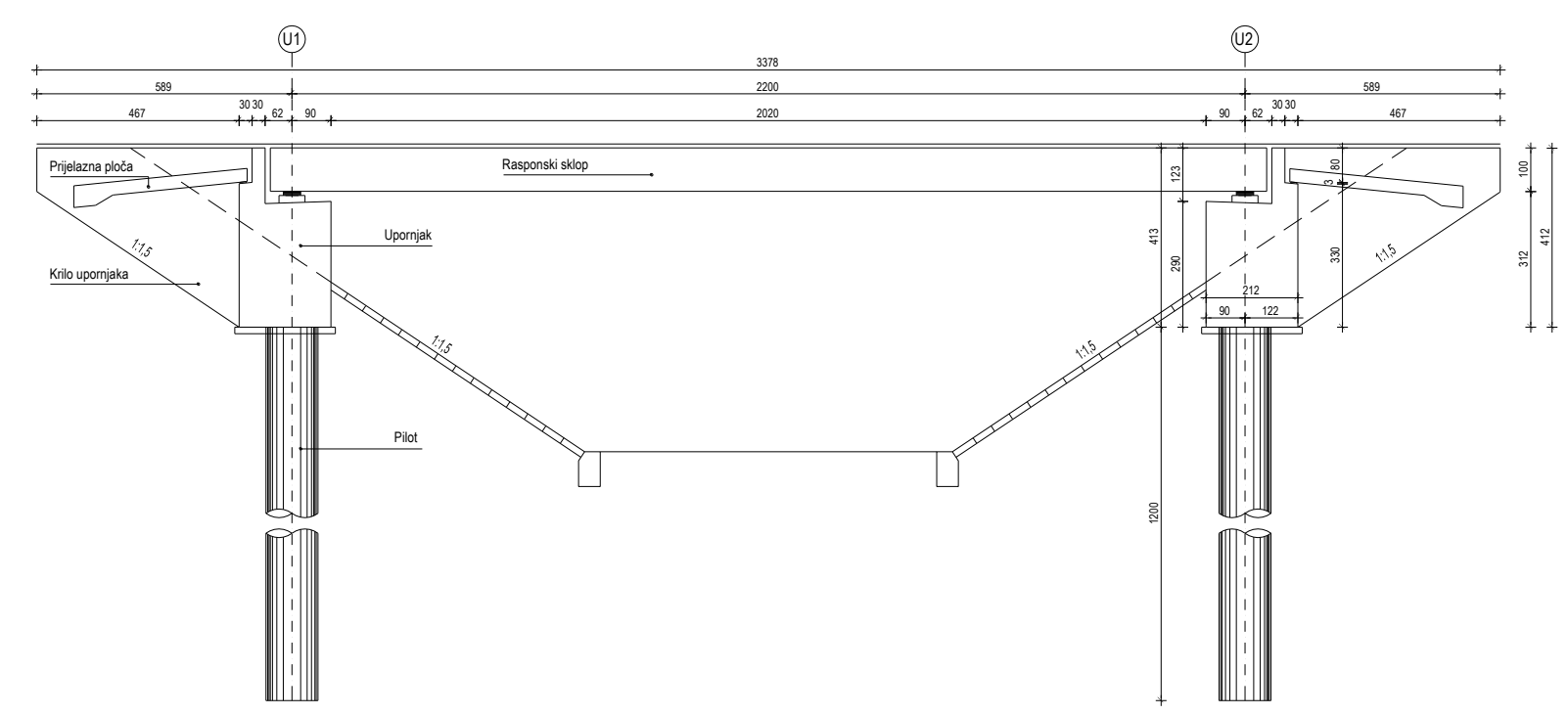

Slika 9 - Uzdužni presjek pločastog mosta

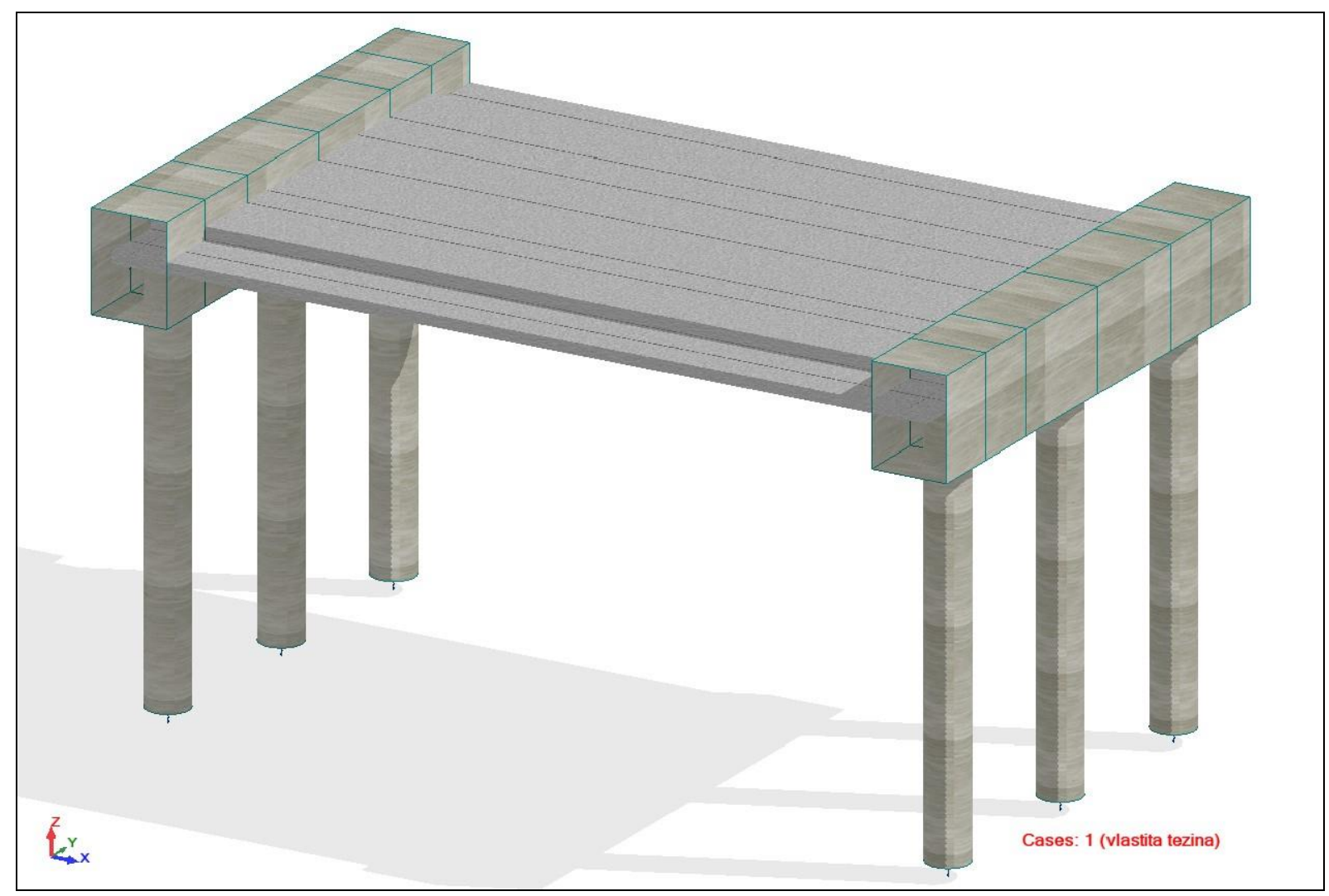

Slika 10 - Model pločastog mosta u programskom paketu Robot Millennium 


\subsection{Opterećenja}

Pregled opterećenja je napravljen prema EN1991. Pregledom je obuhvaćena vlastita težina, slijeganje potpora, skupljanje i puzanje kao stalno djelovanje; temperatura, sila kočenja i prometno opterećenje kao promjenjivo djelovanje, te potresno opterećenje kao izvanredno djelovanje [6].

\section{Vlastita težina}

$\begin{array}{lllll}1 & \text { Asfaltnobetonski zastor } & 23,0 \mathrm{kN} / \mathrm{m}^{3} \times 0,09= & \mathbf{2 , 0 7} & \mathrm{kN} / \mathrm{m}^{2} \\ 2 & \text { Hidroizolacija } & 14,0 \mathrm{kN} / \mathrm{m}^{3} \times 0,01= & \mathbf{0 , 1 4} & \mathrm{kN} / \mathrm{m}^{2} \\ 3 & \text { Hodnik } & 25,0 \mathrm{kN} / \mathrm{m}^{3} \times 0,24= & \mathbf{6 , 0 0} & \mathrm{kN} / \mathrm{m}^{2} \\ 4 & \text { AB ploča } & & & \\ & & & \\ 5 & \text { Rubnjaci } & 25,0 \mathrm{kN} / \mathrm{m}^{3} \times 0,055 \times 2= & & \\ 6 & \text { Predgotov. vijenac } & 25,0 \mathrm{kN} / \mathrm{m}^{3} \times 0,22 \times 2= & 2,75 & \mathrm{kN} / \mathrm{m}^{\prime} \\ 7 & \text { Ograda } & 0,5 \times 2 & 11,00 & \mathrm{kN} / \mathrm{m}^{\prime} \\ 8 & \text { Odbojna ograda } & 0,5 \times 2 & 1,00 & \mathrm{kN} / \mathrm{m}^{\prime} \\ & & \Sigma=1,00 & \mathrm{kN} / \mathrm{m}^{\prime} \\ & & \mathbf{1 5 , 7 5} & \mathrm{kN} / \mathrm{m}^{\prime}\end{array}$

\section{Prometno opterećenje}

Prometno opterećenje uzeto je prema EN1991-2

$\begin{array}{lll}Q_{1 k}= & 240 & \mathrm{kN} \\ q_{1 k}= & 9,0 & \mathrm{kN} / \mathrm{m}^{2} \\ Q_{2 k}= & 160 & \mathrm{kN} \\ q_{2 k}= & 2,5 & \mathrm{kN} / \mathrm{m}^{2} \\ Q_{3 k}= & 80 & \mathrm{kN} \\ q_{3 k}= & 2,5 & \mathrm{kN} / \mathrm{m}^{2} \\ q_{r k}= & 2,5 & \mathrm{kN} / \mathrm{m}^{2}\end{array}$

\section{Sila kočenja}

\begin{tabular}{|c|c|c|c|}
\hline$L=$ & 22 & & \\
\hline$K_{1 k}=$ & $0,60^{*} a_{Q 1}{ }^{*} Q 1+0,1^{*} a_{q 1}{ }^{*} q_{1 k}{ }^{*} W_{1}{ }^{*} L=$ & 203 & k \\
\hline$K_{1 k . u s v}=$ & 203 & $<900$ & \\
\hline
\end{tabular}

\section{Temperatura}

\begin{tabular}{|c|c|c|c|c|}
\hline \multicolumn{2}{|c|}{ Skupina 3} & \multicolumn{2}{|c|}{ Osijek } & \multirow[b]{3}{*}{ Zona 1} \\
\hline Nadmors & & 100 & m.n.m & \\
\hline \multicolumn{4}{|c|}{ Klimatski pojas najviših temperatura } & \\
\hline \multicolumn{4}{|c|}{ Klimatski pojas najnižih temperatura } & Zona 1 \\
\hline$T_{\max , 50}=$ & 37,92 & $\approx$ & 38 & ${ }^{\circ} \mathrm{C}$ \\
\hline$T_{\min , 50}=$ & $-25,32$ & $\approx$ & -26 & ${ }^{\circ} \mathrm{C}$ \\
\hline$T_{e, \max }=$ & 41 & ${ }^{\circ} \mathrm{C}$ & & \\
\hline$T_{e, \min }=$ & -19 & ${ }^{\circ} \mathrm{C}$ & & \\
\hline$\Delta T_{N, \exp }=$ & 31 & ${ }^{\circ} \mathrm{C}$ & & \\
\hline$\Delta T_{N, \text { con }}=$ & -29 & ${ }^{\circ} \mathrm{C}$ & & \\
\hline
\end{tabular}




$\begin{array}{lllllll}\begin{array}{l}\text { Skupljanje i puzanje } \\ R H=\end{array} & & & & & & \\ \text { C30/37 } & 80 & \% & & & & \\ & f_{c k}= & 30 & \mathrm{~N} / \mathrm{mm}^{2} & & & \\ u= & 31,05 & \mathrm{~m} & & & \\ A= & 11,48 & \mathrm{~m}^{2} & & & \\ h_{0}= & 0,739 & \mathrm{~m} & 739,45 & \mathrm{~mm} & \\ \varepsilon_{c a}= & 0,0005 & & & & \\ \varepsilon_{c d}= & 0,00186 & & & & \\ \varepsilon_{c s}= & 2,36 & \% & & & \end{array}$

\section{Slijeganje potpora}

$D_{h}=$

$1,0 \quad \mathrm{~cm}$

\section{Potresno djelovanje}

POTRESNA ZONA

KATEGORIJA TLA

VIII

FAKTOR PONAŠANJA

C

$q=2,0$

\subsection{Kombinacije opterećenja}

Za prethodno analizirana opterećenja napravljene su dvije kombinacije, stalna/prolazna i izvanredna. Ovisno o kombinaciji, korišteni su pripadni parcijalni koeficijenti sigurnosti i koeficijenti kombinacije (tablice 2, 3 i 4) [4], [5].

\section{Tablica 2 - Proračunske kombinacije}

\begin{tabular}{|l|l|}
\hline \multicolumn{1}{|c|}{ Proračunska situacija } & Računska vrijednost djelovanje \\
\hline Stalna/prolazna & $S_{d}=S_{d}\left[\sum_{j}\left(\gamma_{G, j} \cdot G_{k, j}\right)+\gamma_{Q} \cdot Q_{k, 1}+\sum_{j>1}\left(\gamma_{Q} \cdot \psi_{0,1} \cdot Q_{k, i}\right)\right]$ \\
\hline Seizmička & $S_{d}=S_{d}\left[\sum_{j}\left(G_{k, j}\right)+A_{E d}+\left(\psi_{2,1} \cdot Q_{k, 1}\right)\right]$ \\
\hline
\end{tabular}

Tablica 3 - Parcijalni koeficijenti sigurnosti

\begin{tabular}{|c|c|c|c|c|c|}
\hline & \multirow{2}{*}{\multicolumn{2}{|c|}{ Djelovanje }} & \multirow{2}{*}{ Simbol } & \multicolumn{2}{|c|}{ Proračunska situacija } \\
\hline & & & & Stalna/prolazna & Seizmička \\
\hline \multirow{2}{*}{ Stalna opterećenja } & \multicolumn{2}{|l|}{ Nepovoljno } & YGsup & 1,35 & 1,0 \\
\hline & \multicolumn{2}{|l|}{ Povoljno } & YGinf & 1,0 & 1,0 \\
\hline \multicolumn{3}{|l|}{ Slijeganje } & VGset & 1,0 & \\
\hline \multirow[t]{2}{*}{ Prometna djelovanja } & Nepovoljno & $\begin{array}{l}\text { cestovni i pješački } \\
\text { mostovi }\end{array}$ & $Y_{Q}$ & $1,35(1,5)$ & 1,0 \\
\hline & \multicolumn{2}{|l|}{ Povoljno } & $Y Q$ & 0 & 0 \\
\hline \multirow{2}{*}{$\begin{array}{l}\text { Druga promjenjiva } \\
\text { djelovanja }\end{array}$} & \multicolumn{2}{|l|}{ Nepovoljno } & $V_{Q}$ & 1,5 & 1,0 \\
\hline & \multirow{2}{*}{\multicolumn{2}{|c|}{ Povoljno }} & YQ & 0 & 0 \\
\hline Izvanredna djelovanja & & & $Y_{A}$ & & 1,0 \\
\hline
\end{tabular}




\section{Tablica 4 - Koeficijenti kombinacije}

\begin{tabular}{|l|l|c|c|c|}
\hline \multicolumn{1}{|c|}{ Djelovanje } & \multicolumn{1}{c|}{ Simbol } & $\boldsymbol{\psi}_{0}$ & $\boldsymbol{\Psi}$ & $\boldsymbol{\Psi}_{2}$ \\
\hline \multirow{3}{*}{ Prometno djelovanje } & $\begin{array}{l}\text { Gr 1 } \\
\text { (osovinsko opterećenje) }\end{array}$ & 0,75 & 0,75 & 0 \\
\cline { 2 - 5 } & $\begin{array}{l}\text { Model 1 } \\
\text { (kontinuirano opterećenje) }\end{array}$ & 0,4 & 0,4 & 0 \\
\hline Horizontalne sile & \multicolumn{1}{|l}{$\mathrm{T}_{\mathrm{k}}$} & 0 & 0 & 0 \\
\hline Temperatura & 0 & 0,6 & 0,5 \\
\hline
\end{tabular}

\subsection{Naprezanja u ploči i momenti savijanja u naglavnim gredama za različite uvjete oslanjanja}

Kod mostova oslonjenih na tri ležaja preporučuje se postaviti jedan nepomičan i jedan pomičan ležaj u jednom smjeru u srednju ravninu, dok su ostali ležajevi horizontalno pomični u svim smjerovima. Ovakvim smještanjem u srednju ravninu smanjuje se veličina poprečnih pomaka rasponskog sklopa. Prilikom analize, varirani su rasporedi ležajeva kako bi se promotrila promjena naprezanja u ploči te momenata savijanja u naglavnim gredama. Niže, u tablici 5, dan je pregled vrijednosti naprezanja i momenta savijanja samo za mjerodavnu kombinaciju.

Tablica 5 - Naprezanja i momenti savijanja po rasporedima

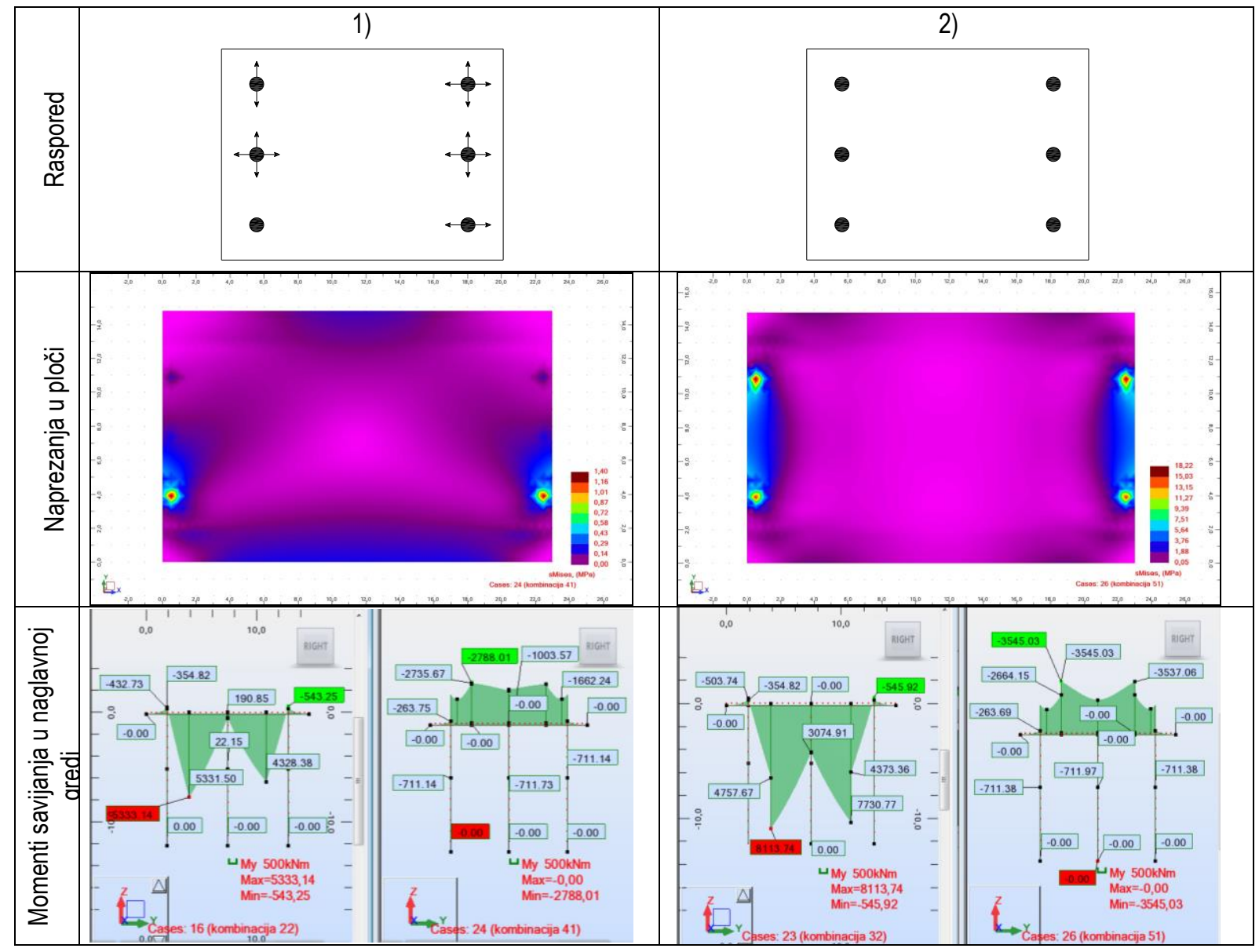




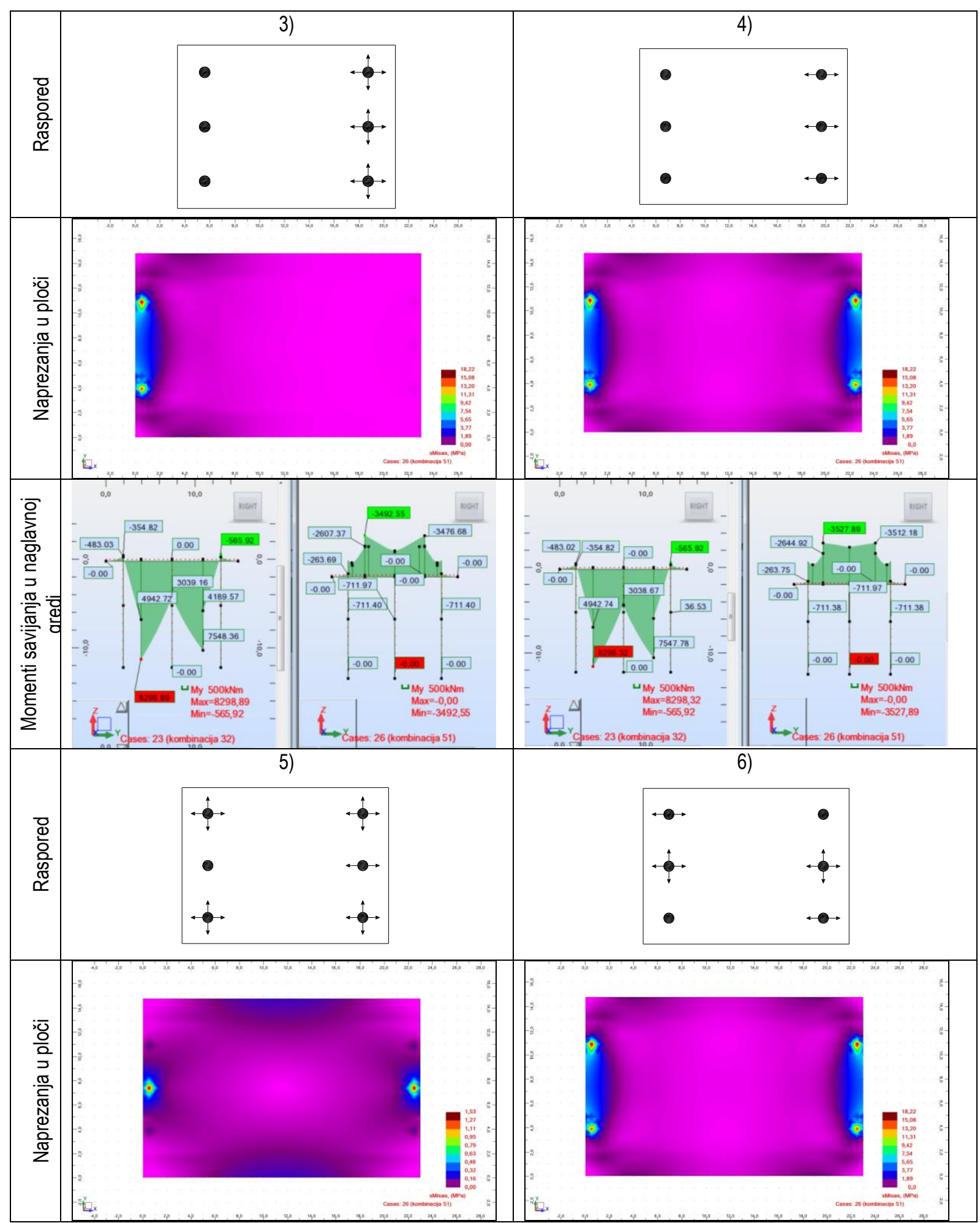




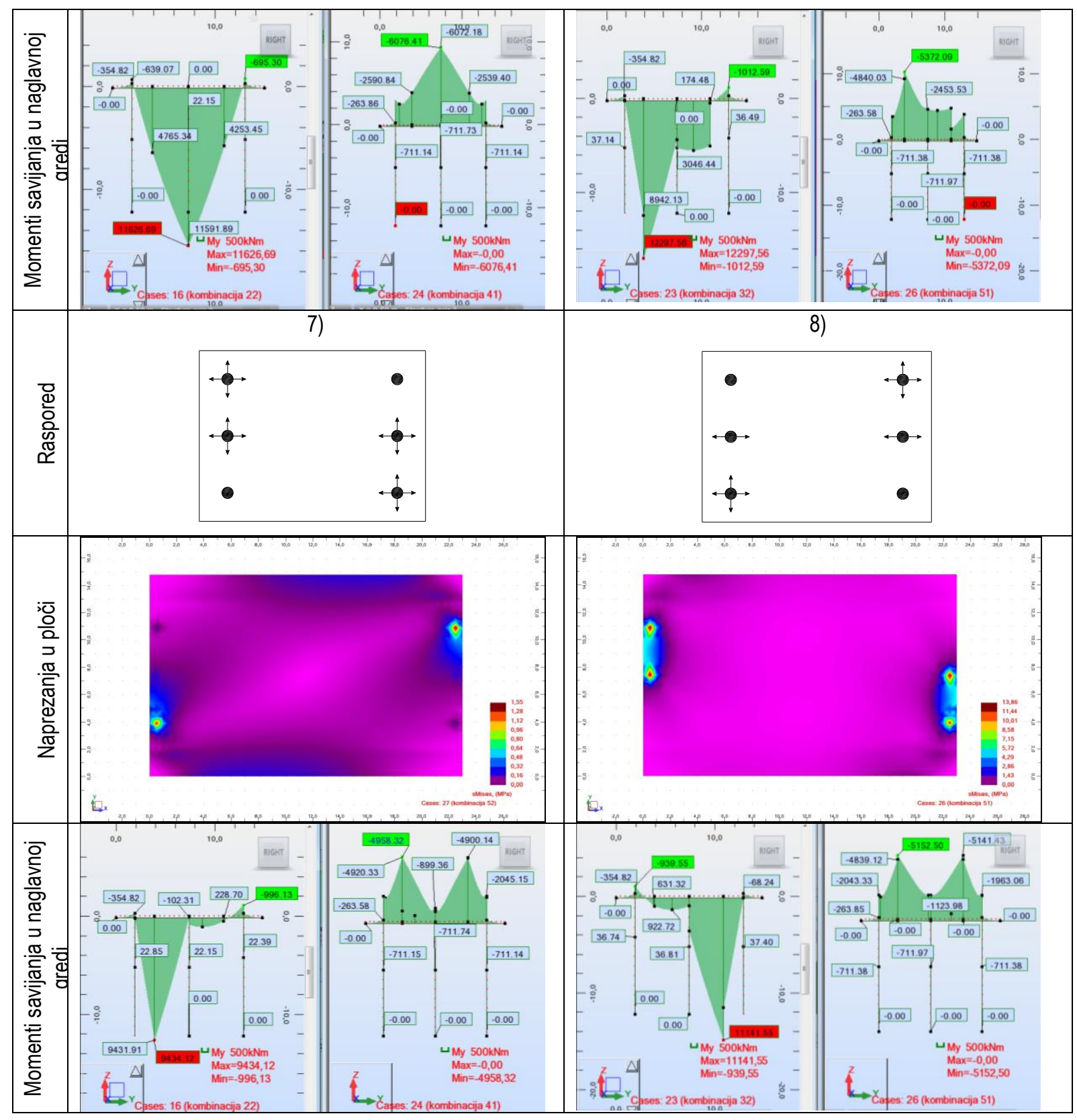

\section{Zaključak}

Prikazan je proračun mosta s nekoliko različith rasporeda ležajeva. Raspored označen brojem 1) je preporučeni raspored te je uzet kao mjerodavan za usporedbu. U svim rasporedima (modelima) je korišten jednak ležaj određene vertikalne i horizontalne krutosti. Usporedbom dobivenih rezultata vidi se pogodnost preporučenoga rasporeda ležajeva. Za takav raspored dobivamo najmanje vrijednosti naprezanja u ploči i najmanje momente savijanja u naglavnim gredama i to za bilo koju kombinaciju opterećenja. Ostale rasporede možemo nazvati nepravilnima te izbor takovoga rasporeda može dovesti do znatnih povećanja naprezanja te momenata savijanja. Ovo povećanje može biti i do 13 puta ako promatramo naprezanja u ploči, te do 3 puta ako promatramo momente savijanja u naglavnim gredama. To ujedno znači znatno veću količinu potrebne armature, te povećane troškove izvedbe. Iz dobivenih rezultata vidimo da je, vodeći se osnovnim principima za izbor tipa i rasporeda ležajeva, moguće ostvariti njihov optimalni raspored za bilo kakav rasponski sklop i statički sustav mosta. 


\section{Literatura}

[1] Ramberger, G.: Structural Bearings and Expansion Joints for Bridges, Structural Engineering Documents 6, IABSE-AIPC-IVBH, Zurich, 2002.

[2] Radić, J.; Mandić, A.; Puž; G.: Konstruiranje mostova, Hrvatska sveučilišna naklada, Sveučilište u Zagrebu Građevinski fakultet, Zagreb, 2005.

[3] Čaušević, M.; Džeba, I.; Dujmović, D.; Markulak, D.; Peroš, B.; Androić, B.: Čelični i spregnuti mostovi, I.A. Projektiranje d.o.o., Zagreb, 2006.

[4] EN1991-1-1: General actions - Densities, self-weight, imposed loads for buildings, CEN, Brusseles, 2002.

[5] EN1991-1-5: General actions - Thermal actions, CEN, Brusseles, 2003.

[6] EN1991-2: Traffic loads on bridges, CEN, Brusseles, 2003. 